HNF-37988

\title{
Toxicological and Structural Consequences From Sodium-Water Reaction in Cell Containing the Secondary Sodium Tank
}

Prepared for the U.S. Department of Energy

Assistant Secretary for Environmental Management

Project Hanford Management Contractor for the

U.S. Department of Energy under Contract DE-AC06-96RL13200

FLUOR.

P.O. Box 1000

Richland, Washington 
HNF-37988

Revision 0

EDC \#: HNF-EDC-08-37989

\section{Toxicological and Structural Consequences From Sodium-Water Reaction in Cell Containing the Secondary Sodium Tank}

Program/Project: FFTF

R. M. Marusich

Fluor Government Group

Date Published

June 2008

Prepared for the U.S. Department of Energy

Assistant Secretary for Environmental Management

Project Hanford Management Contractor for the

U.S. Department of Energy under Contract DE-AC06-96RL13200

\section{FLUOR.}

P.O. Box 1000

Richland, Washington

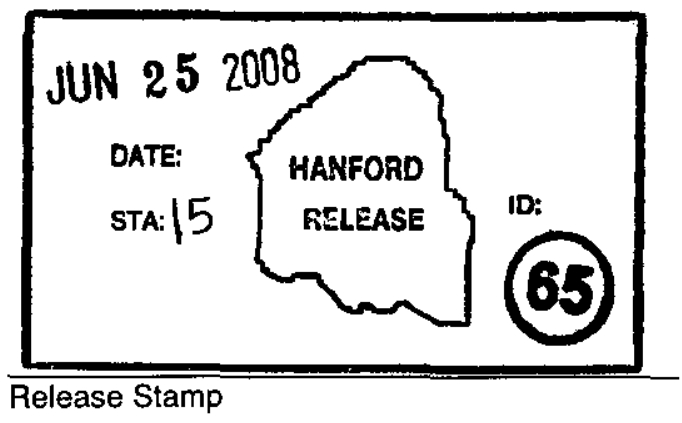


HNF-37988

Revision 0

TRADEMARK DISCLAIMER

Reference herein to any specific commercial product, process,

or service by trade name, trademark, manufacturer, or

otherwise, does not necessarily constitute or imply its

endorsement, recommendation, or favoring by the United

States Government or any agency thereof or its contractors or subcontractors.

This report has been reproduced from the best available copy.

Printed in the United States of America

Total Pages:

27 
HNF-37988 Rev. 0

\title{
TOXICOLOGICAL AND STRUCTURAL CONSEQUENCES FROM SODIUM-WATER
} REACTION IN CELL CONTAINING THE SECONDARY SODIUM TANK

\author{
R. M. Marusich \\ Fluor Government Group \\ June 2008
}


HNF-37988 Rev. 0

This page is intentionally left blank. 
HNF-37988 Rev. 0

\section{Table of Contents}

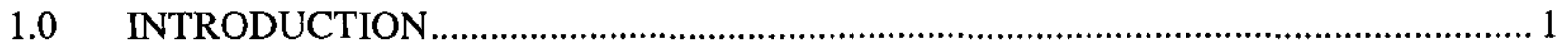

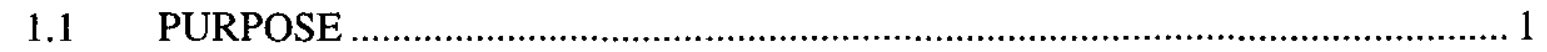

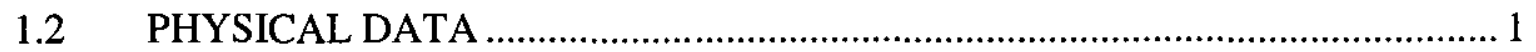

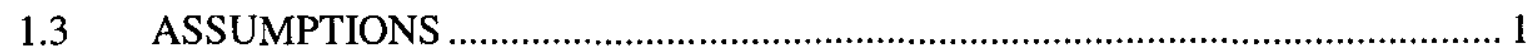

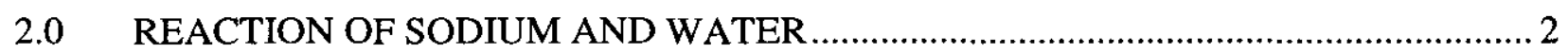

2.1 REACTION EQUATION ....................................................................... 2

2.2 REACTION HEAT AND RESULTS OF AN INSTANTEOUS REACTION ...... 2

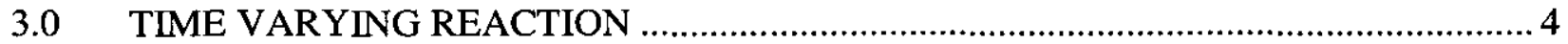

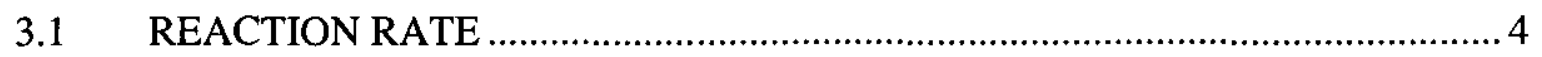

3.2 TOXICOLOGICAL CONSEQUENCES ................................................. 7

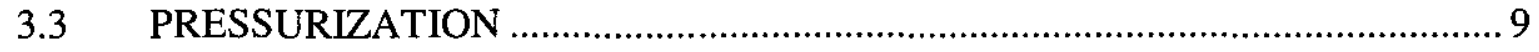

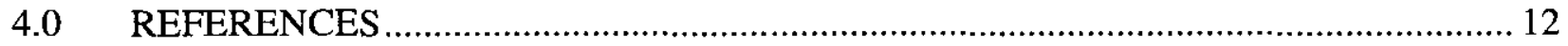

ATTACHMENT 1 - EMAIL FROM TM BURKE TO RM MARUSICH …….......................... 15

ATTACHMENT 2 - MEMO FROM POLZIN TO MARUSICH ……..................................... 15

ATTACHMENT 3 - X/Q FOR THE TOXICOLOGICAL RELEASE ..................................... 18

\section{List of Figures}

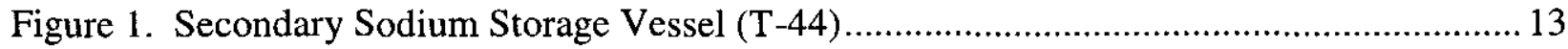

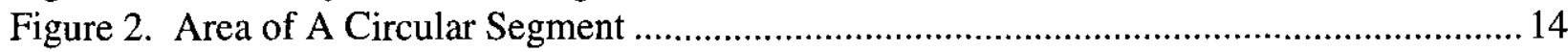


HNF-37988 Rev. 0

This page is intentionally left blank. 
HNF-37988 Rev. 0

\section{Toxicological and Structural Consequences from Sodium-Water Reaction in Cell Containing the Secondary Sodium Tank}

\subsection{INTRODUCTION}

\subsection{PURPOSE}

The analysis will show the consequences should the solid sodium in the Secondary Sodium Tank react with a presumed layer of water in the cell. The Peer Review Checklist is attached.

\subsection{PHYSICAL DATA}

Tank T-44 is the Secondary Sodium Tank. The tank is $12 \mathrm{ft}$ in diameter. The body of the tank is $31 \mathrm{ft}, 8$ inches long ( $31.67 \mathrm{ft})$. There is an ellipsoidal head on both ends. The total length with the heads is $38 \mathrm{ft}, 7.625$ in. The head and shell thicknesses are 1.125 inches each. (Data from Drawing H-4-11713).

Tank T-44 is in a cell. The base of the cell is at El. $503 \mathrm{ft}, 0$ inches. The cell is $24 \mathrm{ft}$ tall, $43 \mathrm{ft}$ long and $20 \mathrm{ft}$ wide (data per drawing H-4-14416). (See Figure 1) The only openings are in the top of the cell.

\subsection{ASSUMPTIONS}

1. 30 gallons of sodium are in Tank T-44 (email from Tom Burke to R. Marusich Attachment 1). The sodium is solid. It is assumed to be evenly distributed over the bottom of Tank T-44.

2. Sodium fills the base of the tank from one end of the barrel to the other. To simplify, the determination of sodium thickness, it is assumed that there is no sodium in the ellipsoidal heads.

3. Pool of water exists on the floor of the cell containing Tank T-44. The depth of the pool is slightly greater than the peak thickness of the solid sodium volume in the tank.

4. Tank T-44 immediately and catastrophically fails such that all of the sodium in the tank enters the water at the same time.

5. Since the sodium density is less than that for water, sodium floats in water. Therefore, the top surface of the solid chunk of sodium does not react with water.

6. The reaction rate, as a function of the area (units of $\mathrm{g} / \mathrm{s}-\mathrm{cm}^{2}$ ) of solid sodium in the water, for a large chunk of solid sodium is the same as that taken from small samples. 
7. All hydrogen from the sodium-water reaction immediately reacts with air on the surface of the sodium due to the heat of the reaction (i.e., hydrogen auto-ignites and "burns" in air).

8. Expansion of the cell air due to the heat of the sodium-water reaction transports the suspended sodium hydroxide out of the cell.

9. The distance to the offsite person is 4.5 miles per FFTF Safety Analysis Report.

\subsection{REACTION OF SODIUM AND WATER}

Per e-mail from Tom Burke to R. Marusich (Attachment 1), 30 gallons of sodium are in the tank. It is assumed that the tank "disappears" instantly (a long crack opens in the base of the tank) and 30 gallons of solid sodium enters a presumed pool of water on the floor of the cell such that all of the sodium reacts.

\section{$2.1 \quad$ REACTION EQUATION}

The reaction is

$$
\mathrm{Na}+\mathrm{H}_{2} \mathrm{O} \rightarrow \mathrm{NaOH}+0.5 \mathrm{H}_{2}
$$

Hydrogen tends to burn immediately in the pressure of air. The sodium hydroxide dissolves in the water.

It is assumed that all of the hydrogen immediately reacts with air as it is generated. Therefore the reaction is

$$
\begin{gathered}
\mathrm{Na}+\mathrm{H}_{2} \mathrm{O} \rightarrow \mathrm{NaOH}+0.5 \mathrm{H}_{2} \\
0.5 \mathrm{H}_{2}+0.25 \mathrm{O}_{2} \rightarrow 0.5 \mathrm{H}_{2} \mathrm{O}
\end{gathered}
$$

or

$$
\mathrm{Na}+0.5 \mathrm{H}_{2} \mathrm{O}+0.25 \mathrm{O}_{2} \rightarrow \mathrm{NaOH}
$$

\subsection{REACTION HEAT AND RESULTS OF AN INSTANTEOUS REACTION}

The heat of reaction is found by subtracting the heat of formation of the reactants from that of the products.

The heats of formation are:

$\begin{array}{ll}\mathrm{H}_{2} & 0 \\ \mathrm{Na} & 0\end{array}$



$\mathrm{O}_{2}$
$\mathrm{H}_{2} \mathrm{O}$ (liquid)
0
$\mathrm{NaOH}$
$-68.3 \mathrm{kcal} / \mathrm{mole}$
-101.96 if $\mathrm{NaOH}$ remains a solid
-112.2 if $\mathrm{NaOH}$ goes into solution at 1 part per 400 parts water.

Assume $\mathrm{NaOH}$ goes into solution as this is most likely the case and, also, is a worst case condition. Then the heat of reaction using, Equation 2, is:

$$
\begin{aligned}
\mathrm{H}_{\text {reaction }} & =-112.2-[(-68.3)(0.5)+1(0)+0.25(0)] \\
& =78 \mathrm{kcal} / \mathrm{mole} \mathrm{Na} \\
& =327 \mathrm{~kJ} / \mathrm{mole} \mathrm{Na}
\end{aligned}
$$

There are 30 gallons of sodium or $0.114 \mathrm{~m}^{3}$. The density of solid sodium is $968 \mathrm{~kg} / \mathrm{m}^{3}$. There is $110 \mathrm{~kg}$ or 4783 moles (using $23 \mathrm{~g} / \mathrm{mole}$ ).

The heat liberated by the reaction is

$$
\begin{aligned}
\mathrm{H} & =(327 \mathrm{~kJ} / \mathrm{mole})(4783 \text { moles }) \\
& =1.56 \times 10^{6} \mathrm{~kJ} \text { or } 1.56 \times 10^{9} \mathrm{~J} .
\end{aligned}
$$

The volume of the cell is determined next. Since the sodium tank has an opening that runs the full length of the tank and is $2 \mathrm{ft}$ wide (see Section 2.1), the void volume within the tank is counted in the volume of the cell. The volume of water on the floor is negligible as compared to the over-all cell volume. The tank volume is

$$
\begin{aligned}
V & =(24 \mathrm{ft})(20 \mathrm{ft})(43 \mathrm{ft}) \\
& =20,640 \mathrm{ft}^{3} \\
& =5.84 \times 10^{5} \mathrm{~L} .
\end{aligned}
$$

At $298 \mathrm{~K}$ and $1 \mathrm{~atm}$ (initial conditions), there is 23,900 moles of air (using the ideal gas law with the gas constant of $0.082 \mathrm{~L}$-atm/mole-K) in $5.84 \times 10^{5} \mathrm{~L}$.

Air is mainly composed of $79 \%$ nitrogen and $21 \%$ oxygen. Therefore, of the 23,900 moles of air in the cell, there are 18,880 moles of nitrogen and 5020 moles of oxygen. After the reaction there are fewer moles of oxygen. One mole of sodium reacts with 0.25 moles of oxygen. There are 4783 moles of sodium. So, after the reaction there are 1196 fewer moles of oxygen. At the completion of the reaction, the total moles in the atmosphere in the cell are 18,880 moles of nitrogen and 3820 moles of oxygen for a total of 22,700 moles. Cell pressurization is due to expansion of the air due to heating.

The average specific heat of nitrogen and oxygen between $300 \mathrm{~K}$ and $3000 \mathrm{~K}$ is $1.18 \mathrm{~J} / \mathrm{g}-\mathrm{K}$ and $1.08 \mathrm{~J} / \mathrm{g}-\mathrm{K}$, respectively (Data from www.engineeringtoolbox.com). Ignore the water vapor that may go into the air by the heat of the reaction and assume all heat goes to the air. The temperature increase is found by the equation below. The heat absorbed by the water and that absorbed by the walls is ignored for conservatism and due to the speed of the reaction (see Section 2.1). The equation is: 
HNF-37988 Rev. 0

$$
\mathrm{Q}=\mathrm{mC}_{\mathrm{v}} \Delta \mathrm{T}
$$

Where $\mathrm{Q}=$ heat added, $\mathrm{kJ}$

$$
\begin{aligned}
& =1.56 \times 10^{9} \mathrm{~J} \\
\mathrm{~m} & =\text { mass in atmosphere, moles } \\
& =18,880 \text { moles of nitrogen } \\
& =3820 \text { moles of oxygen } \\
\mathrm{R} & =\text { ideal gas law constant } \\
& =8.314 \mathrm{~J} / \mathrm{mole}-\mathrm{K} \\
\mathrm{C}_{\mathrm{p}} & =\text { specific heat of nitrogen at constant pressure } \\
& =(1.18 \mathrm{~kJ} / \mathrm{kg}-\mathrm{k})(28 \mathrm{~g} / \mathrm{mole}) \\
& =33 \mathrm{~J} / \mathrm{mole}-\mathrm{K}
\end{aligned}
$$

$\mathrm{C}_{\mathrm{v}}=$ specific heat of nitrogen at constant volume, $\mathrm{J} / \mathrm{mole}-\mathrm{K}$

$=\mathrm{C}_{\mathrm{p}}-\mathrm{R}$

$=24.7 \mathrm{~J} / \mathrm{mole}-\mathrm{K}$

$\mathrm{C}_{\mathrm{p}}=$ specific heat of oxygen at constant pressure

$=(1.08 \mathrm{~kJ} / \mathrm{kg}-\mathrm{k})(32 \mathrm{~g} / \mathrm{mole})$

$=34.6 \mathrm{~J} / \mathrm{mole}-\mathrm{K}$

$\mathrm{C}_{\mathrm{v}}=$ specific heat of oxygen at constant volume, $\mathrm{J} /$ mole- $\mathrm{K}$

$=\mathrm{C}_{\mathrm{p}}-\mathrm{R}$

$=26.3 \mathrm{~J} / \mathrm{mole}-\mathrm{K}$

$\Delta \mathrm{T}=$ temperature rise, $\mathrm{K}$.

Using the end point moles of nitrogen and oxygen (18,880 moles of nitrogen and 3820 moles of oxygen) and solving, yields a value for $\Delta \mathrm{T}$ of $2750 \mathrm{~K}$. The final temperature is $3050 \mathrm{~K}$.

The final pressure, using the ideal gas law with $3050 \mathrm{~K}, 18,880$ moles of nitrogen and 3820 moles of oxygen is $9.7 \mathrm{~atm}$ or 143 psia or $128 \mathrm{psig}$.

\subsection{TIME VARYING REACTION}

\subsection{REACTION RATE}

The sodium-water reaction is not instantaneous, however. Page 12 of Modeling and Control Scoping Study for the ANL-WEST Sodium Facility Reaction Vessel states that a $1 \mathrm{~cm}^{3}$ cube (weighs about 1 gram) of sodium took 10 seconds to fully dissolve in a beaker of water at room temperature.

The density of sodium is $968 \mathrm{~kg} / \mathrm{m}^{3}$ or $0.968 \mathrm{~g} / \mathrm{cm}^{3}$. A $1 \mathrm{~cm}^{3}$ piece weighs $0.968 \mathrm{~g}$. The area of one of the sides is $1 \mathrm{~cm}^{2}$. Assuming the cube floats such that 5 of the 6 sides contact water, the reaction rate is 
HNF-37988 Rev. 0

$\frac{0.968 \mathrm{~g}}{10 \mathrm{~s}}\left(\frac{1}{5 \mathrm{~cm}^{2}}\right)=0.019 \mathrm{~g} / \mathrm{s}-\mathrm{cm}^{2}$ which is rounded up to $0.02 \mathrm{~g} / \mathrm{cm}^{2}-\mathrm{s}$

Sodium fills the bottom of the tank. There are 30 gallons of sodium or $0.114 \mathrm{~m}^{3}$. The tank is $31.67 \mathrm{ft}$ long with ellipsoidal heads. It is assumed that there is no sodium in the ellipsoidal heads to determine the height of solid sodium in the tank, the area of a circular segment must be determined.

The area of a circular segment (see Figure 2) is taken from standard handbook geometrical equations for areas of portions of a circle. The area is:

$$
A=\frac{r^{2}}{2}(\theta-\sin \theta)
$$

Where, in this case $\mathrm{r}=6 \mathrm{ft}$ or $72 \mathrm{in}$.

The volume of sodium is $0.114 \mathrm{~m}^{3}$ or $4 \mathrm{ft}^{3}$. The length of the solid sodium is $31.67 \mathrm{ft}$ (or $9.7 \mathrm{~m}$ ). The area is $0.126 \mathrm{ft}^{2}$ or $18.2 \mathrm{in}^{2}$.

Solving for $\theta$ yields 0.349 radians.

The value of $(r-h)$ is

$$
\cos \left(\frac{\theta}{2}\right)=\frac{(r-h)}{r}
$$

Solving for (r-h) yields 70.91 in. This makes " $h$ " 1.09 inches (as $r$ is 72 inches).

The flat surface of the circular segment is

$$
2 r\left(\sin \frac{\theta}{2}\right)=25 \text { inches }
$$

The arc length given by:

$$
\begin{aligned}
\text { Arclength }=\frac{\pi(12 \mathrm{ft})(0.349 \text { radians })}{(2 \pi \text { radians })} & =2.09 \mathrm{ft} \\
& =25 \mathrm{in} .
\end{aligned}
$$

The section entitled Mensuration Formulas of the Chemical Engineers Handbook provides two equations for the area of a circular segment. They are 


$$
A=\frac{r^{2}}{2}(\theta-\sin \theta)
$$

and

$$
A\left[\left.r^{2} \cos ^{-1}\left(\frac{r-H}{r}\right)\right|_{\rfloor}-(r-H)\left[\left(2 r H-H^{2}\right)^{0.5}\right]\right.
$$

where the terms are as described above using the second equation with $\mathrm{A}=18.2 \mathrm{in}^{2}$ and $\mathrm{r}=72$ in., the value of $\mathrm{H}$ is found to be $1.09 \mathrm{in}$.

Using $\mathrm{H}=1.09$ in. and $\mathrm{r}=72$ in., $(\mathrm{r}-\mathrm{h})$ is 70.9 in. From Figure 1

$$
\frac{\ell}{2}=\left[r^{2}-(r-h)^{2}\right]^{0.5}=12.48 \mathrm{in}
$$

The length $(2 * \ell / 2)$ is 25 in.

The angle $\theta$ is found to be

$$
\begin{aligned}
& a \cos \frac{\theta}{2}=\frac{r-h}{r} \\
& \theta=20^{\circ} \text { or } 0.349 \text { radius }
\end{aligned}
$$

Assume the entire piece enters the water at the same time. Sodium is less dense than is water therefore it floats on the surface but almost submerged. As a result, only the bottom portion will assumed to react. The reaction area is the arc length times length

$$
\begin{aligned}
\text { Reaction area } & =[(25 \mathrm{in} .)(2.54 \mathrm{~cm} / \mathrm{in})][(9.7 \mathrm{~m})(100 \mathrm{~cm} / \mathrm{m})] \\
& =6.16 \times 10^{4} \mathrm{~cm}^{2}
\end{aligned}
$$

It is assumed that the reaction rate found above for small pieces of solid sodium can be applied to large pieces as well. The reaction rate is

$$
\begin{aligned}
\text { Reaction Rate } & =\left(\frac{0.02 \mathrm{~g}}{s-\mathrm{cm}^{2}}\right)\left(6.16 \times 10^{4} \mathrm{~cm}^{2}\right) \\
& =1232 \mathrm{~g}, \mathrm{Na} / \mathrm{s} .
\end{aligned}
$$

Since there are $110 \mathrm{~kg}$ of sodium, the duration of the reaction is: 
HNF-37988 Rev. 0

$$
\begin{array}{r}
\text { duration }=\frac{(110 \mathrm{~kg})(1000 \mathrm{~g} / \mathrm{kg})}{1232 \mathrm{~g} / \mathrm{s}} \\
=90 \mathrm{~s} \text { (rounded up }) .
\end{array}
$$

\subsection{TOXICOLOGICAL CONSEQUENCES}

There are 4 different openings in the ceiling of the cell (see Attachment 2). The ventilation duct penetrates the ceiling in the SW corner of the cell. A pipe chase penetrates the ceiling in the SE corner. Electrical conduit penetrate the ceiling near the center of the cell. An opening exists in the ceiling toward the north end to allow manned entry into the cell. There is a hatch cover over this opening. The pipe chase and electrical conduit are sealed, in that one can not look into the cell, however these seals are not air tight and could be blown out.

For purposes of this analysis it is assumed that all of the generated $\mathrm{NaOH}$ is suspended in the atmosphere of the cell and is transported out of the cell due to expansion of the cell atmosphere caused by the heat generated by the reaction.

The generation rate of sodium hydroxide is found from the chemical reaction in which 1 mole of sodium reacted to form 1 mole of sodium hydroxide.

The generation rate of sodium hydroxide is

$$
\begin{aligned}
\text { NaOH rate } & =\left(\frac{1232 \mathrm{~g}, \mathrm{Na} / \mathrm{s}}{23 \mathrm{~g}, \mathrm{Na} / \mathrm{mole}}\right)\left(\frac{1 \text { mole } \mathrm{NaOH}}{1 \text { mole } \mathrm{Na}}\right) \\
& =53.6 \text { moles }, \mathrm{NaOH} / \mathrm{s} \text { or } 2143 \mathrm{~g}, \mathrm{NaOH} / \mathrm{s} .
\end{aligned}
$$

The sodium hydroxide release from the cell is due to heating of the air causing buoyancy and expansion (like a fire). The energy release rate comes from the reaction rate. Using the reaction where hydrogen burns as it is created.

$$
\mathrm{H}=327 \mathrm{~kJ} / \mathrm{mole}
$$

Then

$$
\begin{aligned}
\frac{d Q}{d t} & =\left(\frac{327 \mathrm{~kJ}}{\text { mole }}\right)\left(\frac{1232 \mathrm{~g}, \mathrm{Na}}{\mathrm{s}}\right)\left(\frac{\text { mole }}{23 \mathrm{~g}}\right) \\
& =1.75 \times 10^{7} \mathrm{~J} / \mathrm{s} \\
& =18 \mathrm{Mw}(\text { rounded up })
\end{aligned}
$$

There are two cases to be considered for toxicological release. The first is the unmitigated case. In this case the heat from the reaction causes the air in the cell to expand. The expanding air carries the $\mathrm{NaOH}$ particles out of the cell into the atmosphere where wind carries it 
downwind. The other case is where the building above the cell exists. The expanding air carries sodium into the building. It can still be transported out of the facility but not as an expanding plume. In this case the release is an area source as the release will travel through a number of external exits to the building, to the atmosphere and then carried downwind as a non-buoyant plume.

The first case considered will be the unmitigated case. The downwind concentration of sodium hydroxide is given by

$$
C=(G)(X / Q)
$$

Where $\mathrm{G}=$ release rate of sodium hydroxide, $\mathrm{mg} / \mathrm{s}$

$$
=2.2 \times 10^{6} \mathrm{mg} / \mathrm{s}(2200 \mathrm{~g} / \mathrm{s})
$$

$\mathrm{X} / \mathrm{Q}=$ measure of atmosphere dispersion, $\mathrm{s} / \mathrm{m}^{3}$ (see below)

$\mathrm{C}=$ concentration, $\mathrm{mg} / \mathrm{m}^{3}$

The X/Q is obtained from a RADIDOSE spreadsheet (see Attachment 3). RADIDOSE is a DOE-approved method for determining consequences (HNF-26181). Numerical values are needed for the following input cells to obtain $\mathrm{X} / \mathrm{Q}$ :

- heat release flag $=4($ Cell $\mathrm{H} 19)$,

- heat release (Mw), (Cell H20),

- diameter of heat release area, $\mathrm{m},($ Cell H21),

- distance to offsite person $=($ Cell H18),

- distance to onsite person $=($ Cell 16)

- Hanford Area of interest $=4$ (Cell H15), and

- All other cells remain at their default value.

In this case

Cell H16 $=100 \mathrm{~m}$, a typical safety analysis value,

Cell H18 $=7243$ m based on a distance of 4.5 miles per the FFTF Safety Analysis Report,

Cell $\mathrm{H} 20=18$ (units are $\mathrm{Mw}$ ),

Cell H21 = $10 \mathrm{~m}$ (see below).

The diameter is taken to be the diameter of a circle whose area equals that of the cell as the larger the diameter, the greater the $\mathrm{X} / \mathrm{Q}$. The cell is $43 \mathrm{ft}$ by $20 \mathrm{ft}$. The equivalent diameter is $33 \mathrm{ft}$ or $10 \mathrm{~m}$. So the input to Cell $\mathrm{H} 21$ is 10 meters.

The X/Q is found to be (See Attachment 3).

- $6.9 \times 10^{-5}$ onsite (Cell G39), and

- $2.6 \times 10^{-6}$ offsite (Cell I39).

Using these values, the sodium hydroxide concentration is 
- $152 \mathrm{mg} / \mathrm{m}^{3}$ onsite, and

- $6 \mathrm{mg} / \mathrm{m}^{3}$ offsite.

The limits for toxicological releases are given in terms of ERPG. For sodium hydroxide

$$
\begin{aligned}
\text { ERPG-1 } & =0.5 \mathrm{mg} / \mathrm{m}^{3} \\
\text { ERPG-2 } & =5 \mathrm{mg} / \mathrm{m}^{3} \\
\text { ERPG-3 } & =50 \mathrm{mg} / \mathrm{m}^{3}
\end{aligned}
$$

The onsite concentration exceeds ERPG-3. The offsite concentration is ERPG-2.

Consider a case where there is some heat transfer to the walls, ceiling and equipment. This assumption is made to see how cooling affects the toxicological release. A lower heat rate results in a lower plume height and greater concentration of sodium hydroxide. For purposes of illustration, assume the cooling is such that the effective heat rate is $4 \mathrm{Mw}$ not $18 \mathrm{Mw}$. This corresponds to the walls, ceiling and equipment absorbing $75 \%$ of the generated heat. Now $\chi / \mathrm{Q}$ is (See Attachment 2)

- $2.8 \times 10^{-4}$ onsite, and

- $8.7 \times 10^{-6}$ offsite.

The concentration is

$616 \mathrm{mg} / \mathrm{m}^{3}$ onsite (exceeds ERPG-3), and

$19 \mathrm{mg} / \mathrm{m}^{3}$ offsite (exceeds ERPG-2).

Even at a lesser heat rate, the effect (in terms of which ERPG is exceeded) remains the same.

Thus for the case of a unmitigated release,

- the onsite concentration (at $100 \mathrm{~m}$ ) exceeds ERPG-3, and

- the offsite concentration exceeds ERPG-2 but not ERPG-3.

The concentrations from both of these calculations are "HIGH Consequences" per Table 2-3 of HNF-8739, Hanford Safety Analysis and Risk Assessment Handbook (SARAH), Rev. 1. As a result there is no need to look at the case of a release into the building. Those results cannot be any worse (in terms of categorization).

\subsection{PRESSURIZATION}

Section 1.4 shows that the cell pressurization is due to expansion of the air due to heating. The final air temperature, shown in Section 1.4 is $3050 \mathrm{~K}$. At $1 \mathrm{~atm}$, and 22,700 moles (endpoint conditions after some oxygen is used in the reaction with sodium), the volume needed to accommodate these conditions is 


$$
\begin{aligned}
V & =\frac{n R T}{P} \\
& =\frac{(22,700 \text { moles })(0.082 \mathrm{~L}-\mathrm{atm} / \text { mole }-K)(3050 \mathrm{~K})}{1 \mathrm{~atm}} \\
& =5.68 \times 10^{6} \mathrm{~L}
\end{aligned}
$$

The initial volume is $5.84 \times 10^{5} \mathrm{~L}$.

Section 2.1 shows that the reaction is over in 90 seconds. The average air flow rate that has to be accommodated to prevent any pressurization is

$$
\frac{5.68 \times 10^{6} L-5.84 \times 10^{5} L}{90 s}=56,600 L / s \text { or } 2000 \mathrm{ft}^{3} / \mathrm{s}
$$

The hatch in the NW part of the cell is $8 \mathrm{ft}$ by $4 \mathrm{ft}$ (scaling off drawing H-4-13119). The area is $32 \mathrm{ft}^{2}$.

Now to find the pressure drop that corresponds to a flow rate of $56,600 \mathrm{~L} / \mathrm{s}$ out of a $32 \mathrm{ft}^{2}$ opening. The Crane Technical Paper 410, Flow of Fluids through Valves, Fittings and Pipe gives equations for compressible flow.

$$
q=6.87 \frac{Y d_{0}^{2} C}{S_{g}}\left(\Delta P \rho_{u}\right)^{0.5}
$$

Where $\mathrm{Y}=$ expansion factor

$=1$ for small values of $\Delta \mathrm{P}$ per $\mathrm{pg}$. A-21 of the reference

$\mathrm{d}_{0}=$ diameter of opening, in.

$=64 \mathrm{in}$. [from hydraulic diameter $=4$ (Area)/(perimeter)]

$\mathrm{C}=$ flow coefficient

$=1.0$ for a nozzle having a small $\mathrm{d}_{\text {nozzle }} / \mathrm{d}_{\text {downstream volume }}$ ratio (see top figure on pg. A-20 of the reference)

$S_{\mathrm{g}}=$ specific gravity of gas relative to air

$=1.0$

$\rho_{\mathrm{u}}=$ upstream density of air, $\mathrm{lb} / \mathrm{ft}^{3}$

$=0.04 \mathrm{lb} / \mathrm{ft}^{3}$ (See below)

$\mathrm{q}=$ flow rate, $\mathrm{ft}^{3} / \mathrm{s}$

$=2000 \mathrm{ft}^{3} / \mathrm{s}($ from $56,600 \mathrm{~L} / \mathrm{s})$

$\Delta \mathrm{P}=$ pressure drop, $\mathrm{psi}$

The density of air at the start of the event is

$$
\text { density at start }=\frac{\left(18,800 \text { moles } \mathrm{N}_{2} * 28 \mathrm{~g} / \text { mole }\right)+\left(5020 \text { moles } \mathrm{O}_{2} * 32 \mathrm{~g} / \text { mole }\right)}{5.84 \times 10^{5} \mathrm{~L}}=1.18 \mathrm{~g} / \mathrm{L}
$$


At the end of the reaction, the density of the atmosphere is

$$
\text { density at end }=\frac{\left(18,800 \text { moles } \mathrm{N}_{2} * 28 \mathrm{~g} / \text { mole }\right)+\left(3820 \text { moles } \mathrm{O}_{2} * 32 \mathrm{~g} / \text { mole }\right)}{5.55 \times 10^{6} \mathrm{~L}}=0.117 \mathrm{~g} / \mathrm{L}
$$

An average upstream value of $0.65 \mathrm{~g} / \mathrm{L}$ or $0.04 \mathrm{lb} / \mathrm{ft}^{3}$ will be used in the analysis.

Solving for $\Delta \mathrm{P}$ yields $0.13 \mathrm{psig}$.

The pressure difference between the cell holding Tank T-44 and the area into which the air flows is small. This means that the area into which the air flows is also pressurizing. This area is the cell above the cell containing Tank T-44.

Now consider the conditions in the cell holding Tank T-44 and in the cell above. The cell above is $22 \mathrm{ft}$ wide, $56 \mathrm{ft}$ long (to the wall south of $\mathrm{Y}-9$ and $\mathrm{Y}-12$ ) and $17.75 \mathrm{ft}$ tall (assuming that the ceiling is $2 \mathrm{ft}$ thick (scaled off of the drawing). The volume is $6.2 \times 10^{5} \mathrm{~L}$. The volume is about the same as the cell holding Tank T-44.

The number of moles in the cell above is 25,400 at 1 atm and $298 \mathrm{~K}$. Assume no cooling and complete mixing such that the temperature rise in both rooms is half that in the cell holding Tank T-44 or one-half of $2750 \mathrm{~K}$ or $1375 \mathrm{~K}$. The final temperature in both cells is $1673 \mathrm{~K}$. The total moles in both rooms is

Total moles $=18,880+3820+25,400=48,100$ moles.

Using the ideal gas law with 48,100 moles, $1673 \mathrm{~K}$ and $1.2 \times 10^{6} \mathrm{~L}$, yields a final pressure of $5.5 \mathrm{~atm}$ or $66 \mathrm{psig.}$

The effects of the pressure increase are as follows:

- The ventilation duct will likely be blown out at some location. If the duct can withstand the forces due to the flow resulting from a pressure of $65 \mathrm{psig}$, the filters will be blown out.

- The North wall (wall between equipment E-604 and Y-9 and Y-12) does not appear to be a substantial wall and as a result will likely fail.

- $\quad$ The hatch cover and the packing in the electrical and piping penetration between the cell holding Tank T-44 and the cell above will blow out. Drawing H-4-13123 shows what appears to be a concrete block wall in the East wall of the cell above that which holds Tank T-44. If this is the case, the block will be blown out.

- $\quad$ The cell adjoining the one above that holding Tank T-44 will be pressurized and experience similar structural failures as those listed above, if the wall is concrete block. This effect could cascade into other cells depending on the details of construction, the large flow paths to other cells (e.g., stairways) and speed of cooling. 
HNF-37988 Rev. 0

\subsection{REFERENCES}

H-4-11713, 1977, Design Layout Drawing for Vessel T-44, Rev. 2, Westinghouse Hanford Company, Richland, Washington.

H-4-13123, 1975, Equipment Location HTS Service BLDG West Sect GC-GC, Rev. 6, Westinghouse Hanford Company, Richland, Washington.

H-4-14416, 1974, HTS Service Building West Substr. Tank T-44 Cell Conc. Outline and Reinf., Rev. 3, Westinghouse Hanford Company, Richland, Washington.

Modeling and Control Scoping Study, www.mne.psu.edu/edwards/PROJECTS/SPF/REPORT.pdf (website of Dr. Robert M. Edwards, Professor of Nuclear Engineering, Pennsylvania State University).

Crane Technical Paper No. 410, 1957, Flow of Fluids Through Valves, Fittings, and Pipe, Crane Company, Chicago, Illinois.

HNF-8739, 2004, Hanford Safety Analysis and Risk Assessment Handbook (SARAH), Rev. 1, Fluor Hanford, Inc., Richland, Washington.

HNF-26181, 2005, Users Guide and Model Description for RADIDOSE Version 3.0, Rev. 0, Fluor Hanford, Inc., Richland, Washington.

Perry, R. H., C. H. Chilton, and S. D. Kirkpatrick, 1997, Perry's Chemical Engineers' Handbook, 7th edition, McGraw-Hill Book Company, Inc., New York, New York. 


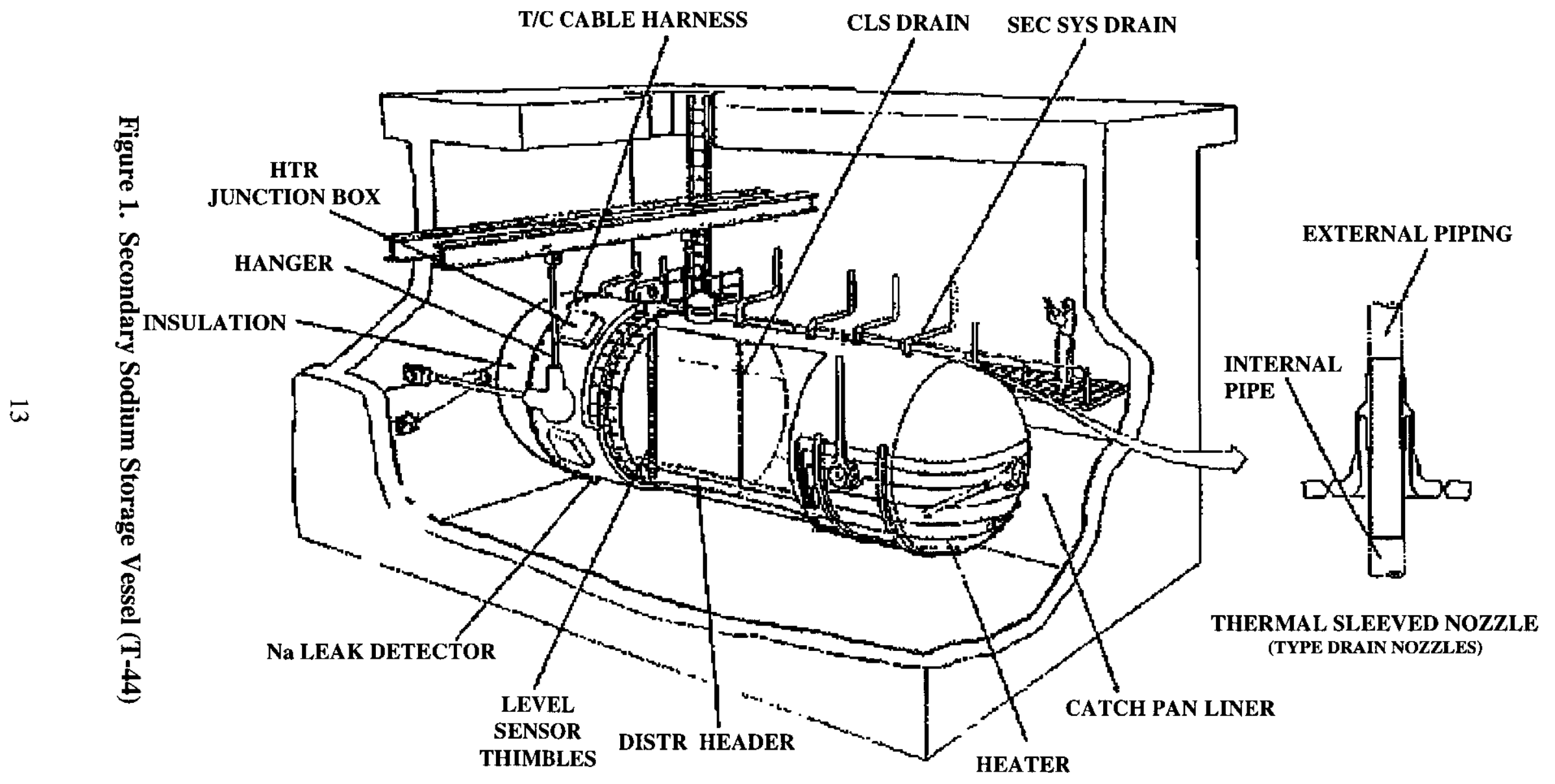

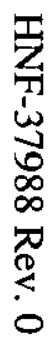


HNF-37988 Rev. 0

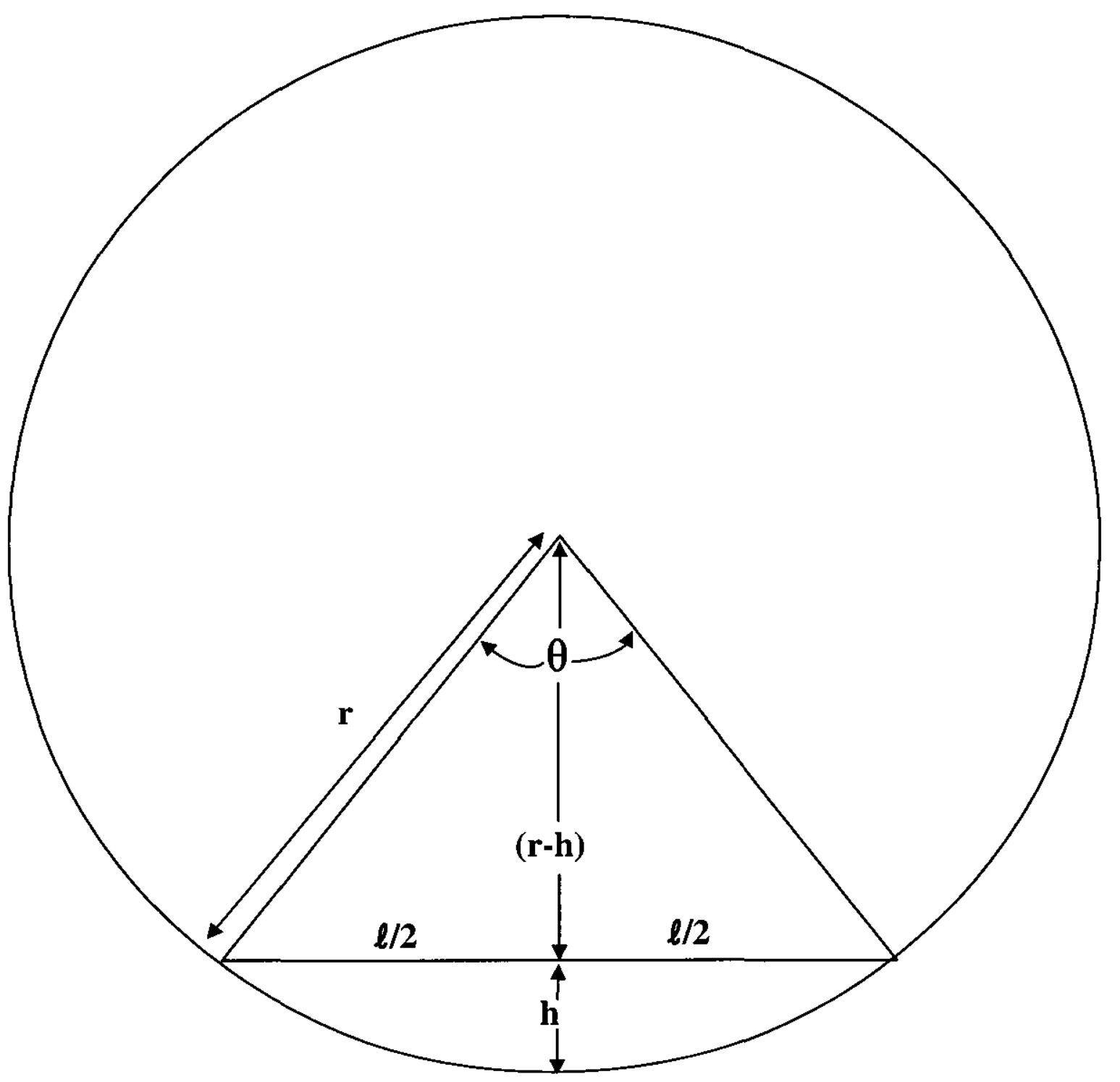

Figure 2. Area of A Circular Segment 


\title{
ATTACHMENT 1 - EMAIL FROM TM BURKE TO RM MARUSICH
}

\author{
From: Burke, Thomas $M$ (Tom)
}

Sent: Friday, February 29, 2008 3:43 PM

To: Marusich, Robert $M$

Subject: Analysis of Sodium-Water Reaction and Hydrogen "Burn"

Bob,

I participated in a Hazard Analysis Table Top this afternoon in support of FFTF preparing to go into a long term S\&M condition. Other participants were Bill Dautel, John Dale, Dave Polzin, Ed Dodd, Bernie Nowack, and Jeff Marusich. One of the "events" we decided to have analyzed is a sodium water-reaction in the cell containing our secondary sodium storage tank which has an estimated 30 gallons of residual sodium remaining in it. It was suggested that you would be the best person to do the analysis. Here is the scenario:

- A large quantity of water accumulates in the cell containing the tank

- The tank essentially "disappears" by some unspecified mechanism (corrosion over a long period of time?)

- The 30 gallons of sodium react completely with the water $(\mathrm{Na}+\mathrm{H} 2 \mathrm{O}=>\mathrm{NaOH}+1 / 2 \mathrm{H} 2+$ Heat)

- All of the hydrogen generated is retained in the cell and mixes with the air in the cell (free volume of 13,100 $\mathrm{ft} 3$ per HEDL-TME 75-122). I assume the mixture will be above the LFL. - It ignites. All of the energy from the hydrogen burn as well as the original sodium-water reaction raise the pressure in the cell (assume no leakage even though there certainly will be). What is the pressure? Is it really a detonation and treated differently than just raising the pressure?

I tried to quickly find the "design" or allowable pressure for the cell but couldn't. Maybe Bill or Dave can do that next week. I guess they'll also have to provide you with a charge code.

If you have any questions, contact me, Bill or Dave.

Thanks,

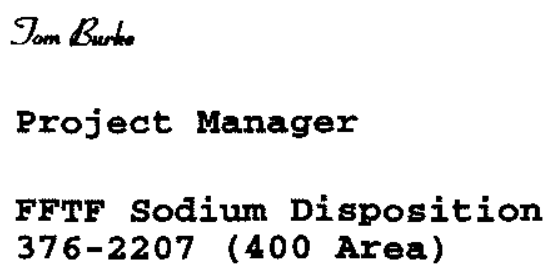


HNF-37988 Rev. 0

\section{ATTACHMENT 2 - MEMO FROM POLZIN TO MARUSICH}

From: Polzin, David L (Dave)

Sent: Thursday, March 27, 2008 4:23 PM

To: Marusich, Robert $M$

Cc: Dautel, William A; Burke, Thomas M (Tom)

Subject: RE: Additional Data needs - Analysis of Sodium-Water Reaction and Hydrogen "Burn"

Bob,

There are 4 different openings in the floor of cell 431 that connect to cell 401 below. The H\&V ducts go through an opening in the southwest corner, some piping goes through an opening in the southeast corner, some electrical conduit goes through an opening along the east wall (near the center of the room), and there is an opening toward the north end along the east wall for manned entry into cell 401 . Most of these openings are closed off to some extent with grating, diamond plate, or piping/ducting/conduit passing through. If the hatch cover is open above the entry ladder into cell 401, you can look down and see the tank, piping, etc. I would also note that cell 401 communicates with a couple of pipe ways through openings in the walls. These are shown on drawing H-4-13123 and H-4-13689. Cell 401 is definitely not an air-tight cell.

Dave 


\section{Marusich, Robert M}

To:

Subject:
Marusich, Robert M

RE: OUO Determination for Toxicological and Structural - Hydrogen From The Secondary Sodium Tank

Message forwarded from W. Dautel, FFTF concerning the OUO status of the paper,

-----Original Message---...

From: Witherspoon, Wiley V III

Sent: Tuesday, June 10, 2008 3:05 PM

To: Niebel, Sheryl A (Sheri)

Subject: RE: Coveer sheet - Toxicological and Structural - Hydrogen From The Secondary.doc

I think it is a stretch to get to $0 U 0$ \# 2. The closest I can get is "Can the information be used to gain access to key component of the facility to disrupt operations or harm employees?" This does not tell how to gain access, but it does give parameters used in the equation that could be used to disrupt or harm if someone could interpret and then invoke. I say no to OUO at this time. Wiley

Wiley Witherspoon PMP, CM

Program Office Manager

FFTF Fuel Offload and Asset Management

509-376-1805

509-376-4920 fax

wiley_v_iii_witherspoon@rl.gov

-...-Original Message-....

From: Dautel, William A

Sent: Monday, June 09, 2008 4:12 PM

To: Burke, Thomas M (Tom); Niebel, Sheryl A (Sheri)

Subject: FW: Coveer sheet - Toxicological and Structural - Hydrogen From The Secondary.doc

Tom \& Sheri,

It looks okay to me. I know of no reason that this would have to be $0 U 0$.

Bill Dautel

$373-9563$

-----Original Message-----

From: Marusich, Robert $M$

Sent: Monday, June 09, 2008 3:58 PM

To: Dautel, William A

Subject: Coveer sheet - Toxicological and Structural - Hydrogen From The Secondary.doc

Bill, 


\title{
ATTACHMENT 3 - X/Q FOR THE TOXICOLOGICAL RELEASE
}

$\mathrm{X} / \mathrm{Q}$ for the toxicological release for the FFTF sodium-water and hydrogen-air reaction which creates sodium hydroxide.

\author{
Case 1: \\ $\mathrm{Q}=18 \mathrm{Mw}$ \\ Effective pool diameter $=10 \mathrm{~m}$
}

\begin{tabular}{|c|c|c|c|c|c|c|c|c|}
\hline & $\mathrm{E}$ & $\mathrm{F}$ & $\mathrm{G}$ & $\mathrm{H}$ & $I$ & $\mathbf{J}$ & $\mathrm{K}$ & $\mathrm{L}$ \\
\hline 1 & \multicolumn{8}{|c|}{ RADIDOSE Version $3.0(5-18-2005)$} \\
\hline 2 & \multicolumn{3}{|c|}{ Input Parameter } & User Input & Default & \multicolumn{3}{|c|}{ Description (based on user input) } \\
\hline 3 & \multicolumn{4}{|c|}{ Facility/Material (1-14): } & 1 & \multicolumn{3}{|c|}{ Plutonium Finishing Plant: $<10 \% \mathrm{Pu}-240$} \\
\hline 4 & \multicolumn{4}{|c|}{ Form of Material $(1-10)$ : } & 7 & \multicolumn{3}{|c|}{ Pu Oxide and Other Powders } \\
\hline 5 & \multicolumn{4}{|c|}{ Accident Type (1-6): } & 1 & \multicolumn{3}{|c|}{ Fire } \\
\hline 6 & \multicolumn{4}{|c|}{ Quantity at Risk (MAR): } & 1 & \multirow{2}{*}{\multicolumn{3}{|c|}{ gram }} \\
\hline 7 & \multicolumn{4}{|c|}{ Damage Ratio: } & 1 & & & \\
\hline 8 & \multicolumn{4}{|c|}{ Airborne Release Fraction: } & $6.00 \mathrm{E}-03$ & \\
\hline 9 & \multicolumn{4}{|c|}{ Respirable Fraction: } & 0.1 & \multicolumn{3}{|c|}{$\begin{array}{l}\text { ARF from SARAH Table 3-4 (ARF page) } \\
\text { RF from SARAH Table 3-4 (ARF page) }\end{array}$} \\
\hline 10 & \multirow{2}{*}{\multicolumn{4}{|c|}{$\begin{array}{l}\text { Leak Path Factor: } \\
\text { HEPA Filter Factor. }\end{array}$}} & 1 & \\
\hline 11 & \multicolumn{3}{|c|}{ HEPA Filter Factor: } & & 1 & \multicolumn{3}{|c|}{$\begin{array}{l}\text { LPF (applies to particulate only) } \\
\text { DF }=1 \text { (applies to particulate only) }\end{array}$} \\
\hline 12 & & 3 & \multicolumn{3}{|c|}{ ICRP $68,5 \mu \mathrm{m}$ AMAD } \\
\hline 13 & & Onsite \& Offsite Pul & lic Dose Factor: & & 7 & \multicolumn{3}{|c|}{ ICRP 72 for Adult } \\
\hline 14 & \multicolumn{4}{|c|}{ Material Solubility Class: } & 3 & \multicolumn{3}{|c|}{ compounds are generally insoluble } \\
\hline 15 & & Hanford Proce & ssing Area (1-4): & 4 & & 400 Area & & \\
\hline 16 & & stance or $\mathrm{X} / \mathrm{Q}$ for $\mathrm{Co}$ & llocated Worker: & & 100 & meters & & \\
\hline 17 & & Distance or X/Q $\mathrm{f}$ & or Onsite Public: & & 4,210 & meters & & \\
\hline 18 & & Distance or $\mathrm{X} / \mathrm{Q} \mathrm{fc}$ & Offsite Public: & 7240 & & meters & & \\
\hline 19 & & Emission So & urce Type (1-4): & 4 & & Ground level fir & & \\
\hline 20 & & Thermal Power & $(2$ to $1000 \mathrm{MW})$ : & 18 & & $\mathrm{MW}$ (at $0.23 \mathrm{~W}$ & $\left.1 / \mathrm{m}^{2}\right)$ & \\
\hline 21 & & Pool Fire Dian & eter $(1$ to $20 \mathrm{~m})$ : & 10 & & meters (Area = & $\left.78.5 \mathrm{~m}^{2}\right)$ & \\
\hline 22 & & & & & & & & \\
\hline 23 & & Description of Acc & ident Scenario: & & Edit & sing function key $F$ & 2. Carriag & ns are not allowed. \\
\hline 24 & & & & & & & & \\
\hline 25 & & & & & & & & \\
\hline 26 & & & & & & & & \\
\hline 27 & Offiste & $\mathrm{X} / \mathrm{Q}$ based on distar & ice from FFTF to & he Site Bound & dary which is 4.5 & miles. & & \\
\hline 28 & & & & & & & & \\
\hline$\frac{20}{29}$ & & & & & & & & \\
\hline 30 & & Dose Results for th & Postulated Acc & dent: & & & & \\
\hline 31 & & Plutonium Finishi & ng Plant: $<10 \%$ & $\mathrm{Pu}-240-\mathrm{New}$ & composition (20 & & Materia & ce amounts are \\
\hline 32 & & & Pu Ox & and Other & Powders & : & listed on & UnitDF" page. \\
\hline 33 & & Ground Level Fir & $e-18 \mathrm{MW}=10$ & m Diameter & & 400 Area & & \\
\hline 34 & & Total Res & pirable Release: & $6.00 \mathrm{E}-04$ & gram & & & \\
\hline 35 & & Dose Factors: & ICRP $68,5 \mu \mathrm{m}$ & & P 72 for Adult & Release & & \\
\hline 36 & & & Collocated & Onsite & Offsite & Duration & & \\
\hline 37 & & Receptor: & Worker & Public & Public & th & & \\
\hline 38 & & Distance: & $100 \mathrm{~m}$ & $4,210 \mathrm{~m}$ & $7,240 \mathrm{~m}$ & & & \\
\hline 39 & & X/Q: & $6.88 \mathrm{E}-05$ & $2.74 \mathrm{E}-06$ & $2.59 \mathrm{E}-06$ & $\mathrm{~s} / \mathrm{m} 3$ & & \\
\hline
\end{tabular}


HNF-37988 Rev. 0

Case 2:

$\mathrm{Q}=4 \mathrm{Mw}$

Effective pool diameter $=10 \mathrm{~m}$

\begin{tabular}{|c|c|c|c|c|c|c|c|c|}
\hline & E & $\mathrm{F}$ & $\mathrm{G}$ & $\mathbf{H}$ & I & $\mathbf{J}$ & $\mathbf{K}$ & $\mathrm{L}$ \\
\hline 1 & \multicolumn{8}{|c|}{ RADIDOSE Version $3.0(5-18-2005)$} \\
\hline 2 & \multicolumn{3}{|c|}{ Input Parameter } & User Input & Default & \multicolumn{3}{|c|}{ Description (based on user input) } \\
\hline 3 & \multicolumn{4}{|c|}{ Facility/Material (1-14): } & 1 & \multicolumn{3}{|c|}{ Plutonium Finishing Plant: $<10 \% \mathrm{Pu}-240$} \\
\hline 4 & \multicolumn{4}{|c|}{ Form of Material (1-10): } & 7 & \multicolumn{3}{|c|}{ Pu Oxide and Other Powders } \\
\hline 5 & \multicolumn{4}{|c|}{ Accident Type (1-6): } & 1 & \multicolumn{3}{|c|}{ Fire } \\
\hline 6 & \multirow{2}{*}{\multicolumn{4}{|c|}{$\begin{array}{r}\text { Quantity at Risk (MAR): } \\
\text { Damage Ratio: }\end{array}$}} & 1 & \multicolumn{3}{|l|}{ gram } \\
\hline 7 & & & & & 1 & & & \\
\hline 8 & \multicolumn{4}{|c|}{ Airborne Release Fraction: } & $6.00 \mathrm{E}-03$ & \multicolumn{3}{|c|}{ ARF from SARAH Table 3-4 (ARF page) } \\
\hline 9 & \multicolumn{4}{|c|}{ Respirable Fraction: } & 0.1 & \multicolumn{3}{|c|}{ RF from SARAH Table 3-4 (ARF page) } \\
\hline 10 & \multicolumn{4}{|c|}{ Leak Path Factor: } & 1 & \multicolumn{3}{|c|}{ LPF (applies to particulate only) } \\
\hline 11 & \multicolumn{4}{|c|}{ HEPA Filter Factor: } & 1 & \multicolumn{3}{|c|}{$\mathrm{DF}=1$ (applies to particulate only) } \\
\hline 12 & \multicolumn{4}{|c|}{ Collocated Worker Dose Factor: } & 3 & \multicolumn{3}{|c|}{ ICRP $68,5 \mu \mathrm{m}$ AMAD } \\
\hline 13 & \multicolumn{4}{|c|}{ Onsite \& Offsite Public Dose Factor: } & 7 & \multirow{2}{*}{\multicolumn{3}{|c|}{$\begin{array}{l}\text { ICRP } 72 \text { for Adult } \\
\text { compounds are generally insoluble }\end{array}$}} \\
\hline 14 & \multicolumn{4}{|c|}{ Material Solubility Class: } & 3 & & & \\
\hline 15 & & Hanford Proce & sing Area (1-4): & 4 & & \multicolumn{3}{|c|}{400 Area } \\
\hline 16 & & stance or $\mathrm{X} / \mathrm{Q}$ for $\mathrm{Co}$ & located Worker: & & 100 & meters & & \\
\hline 17 & & Distance or $\mathrm{X} / \mathrm{Q} \mathrm{f}$ & r Onsite Public: & & 4,210 & meters & & \\
\hline 18 & & Distance or $\mathrm{X} / \mathrm{Q} \mathrm{fc}$ & I Offsite Public: & 7240 & & meters & & \\
\hline 19 & & Emission So & urce Type (1-4): & 4 & & Ground level fir & & \\
\hline 20 & & Thermal Power & 2 to $1000 \mathrm{MW}$ ): & 4 & & MW (at $0.05 \mathrm{~W}$ & $\left.1 / \mathrm{m}^{2}\right)$ & \\
\hline 21 & & Pool Fire Dian & eter $(1$ to $20 \mathrm{~m})$ : & 10 & & meters (Area $=$ & $\left.78.5 \mathrm{~m}^{2}\right)$ & \\
\hline 22 & & & & & & & & \\
\hline 23 & & Description of Acc & dent Scenario: & & Edit & sing function key $F$ & 2. Carriag & ns are not allowed. \\
\hline 24 & & & & & & & & \\
\hline 25 & & & & & & & & \\
\hline 26 & & & & & & & & \\
\hline 27 & inste & $X N Q$ based on distar & ice trom FFTF to & ne site boun & ry when is 4.5 & miles. & & \\
\hline 28 & & & & & & & & \\
\hline 29 & & & & & & & & \\
\hline 30 & & Dose Results for th & e Postulated Ac & lent: & & & & \\
\hline 31 & & Plutonium Finishi & ag Plant: < 10\% & $\mathrm{u}-240 \ldots \mathrm{Neu}$ & omposition (2 & & Materia & ce amounts are \\
\hline 32 & & & Pu Ox & e and Other & wders & & listed on & UnitDF" page. \\
\hline 33 & & Ground Level Fir & e $-4 \mathrm{MW}=10$ & m Diameter & & 400 Area & & \\
\hline 34 & & Total Res & pirable Release: & $6.00 \mathrm{E}-04$ & gram & & & \\
\hline 35 & & Dose Factors: & ICRP $68,5 \mu \mathrm{m}$ & ICF & 72 for Adult & Release & & \\
\hline 36 & & & Collocated & Onsite & Offsite & Duration & & \\
\hline 37 & & Receptor: & Worker & Public & Public & $1 \mathrm{~h}$ & & \\
\hline 38 & & Distance: & $100 \mathrm{~m}$ & $4,210 \mathrm{~m}$ & $7,240 \mathrm{~m}$ & & & \\
\hline 39 & & $\mathrm{X} / \mathrm{Q}:$ & $2.80 \mathrm{E}-04$ & $1.22 \mathrm{E}-05$ & $8.67 \mathrm{E}-06$ & $\mathrm{~s} / \mathrm{m} 3$ & & \\
\hline
\end{tabular}




\section{REVIEW CHECKLIST}

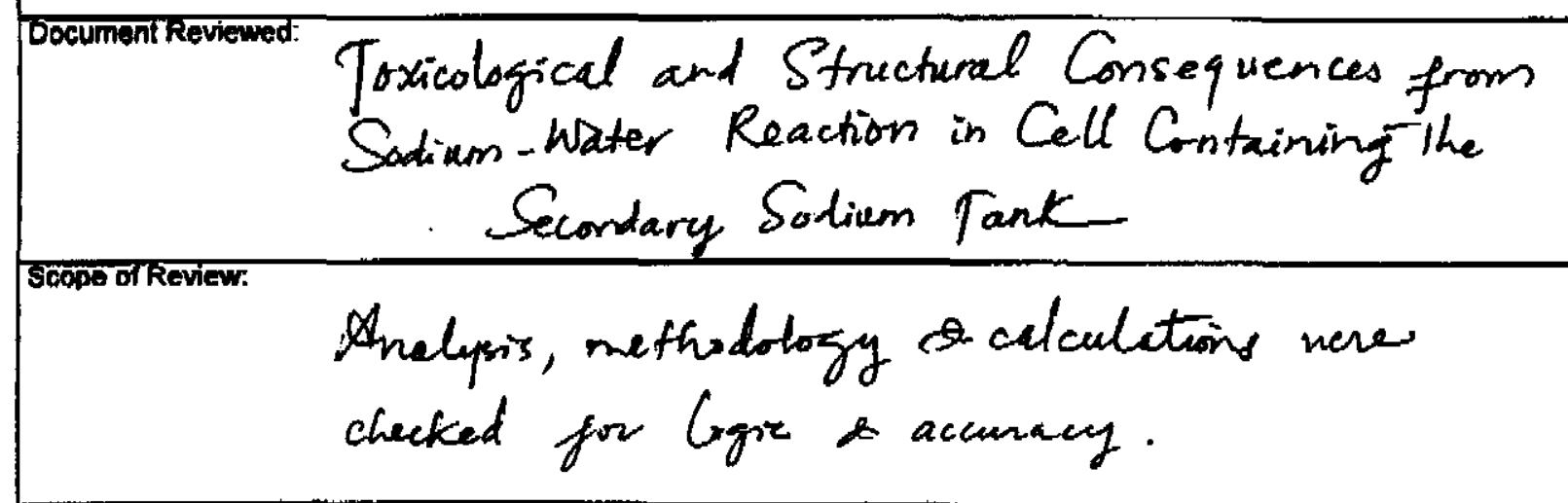

\footnotetext{
Yes No NA

O 01 - Provious roviews complete and cover analysis, up to scope of this review, with no gaps.

Q 00 Problem completely defined.

$\otimes 00 \quad 0 \quad$ Accident scenarios developed in a clear and logical manner.

Q 00 Necessary assumptions explicitly stated and supported.

Q 00 computer codes and data fles documented.

Q 00 Data used in calculations explicitly stated in document.

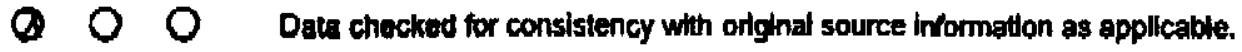

2. 00 Mathematical derivation checked induding dimensional consistercy of results.

O $Q$ Models appropriate and used within range of validity or use outside range of established vellitity juathied.

Q 00 Hand colculationu chacked for orron. Sproadsheot results should be treated exactly the same as hand calculatione.

O $0 \otimes$ Software input correct and condetent whth document reviewed.

O $0 \otimes$ Sotware output consistent with input and whe resulis reported in document reviowed.

Q 00 Limits/criteria/guidelines applied to analysis results are appropriate and reforenced.

Limits/criteria/guidelines checked againat references.

O $O \&$ Safely margins consistent with good enginaering practices.

Q $0 \quad 0$ Concluajons conslstent with analytical results and applicable limits.

Q 00 Results and conclusions address all points required in the problem statement.

O O \& Format conalstent with appropilato NRC Regulatory Guide or other standards.

O OQ Review ealeulations. comments, and/or notes are attached.

- 00 Document approved.
}

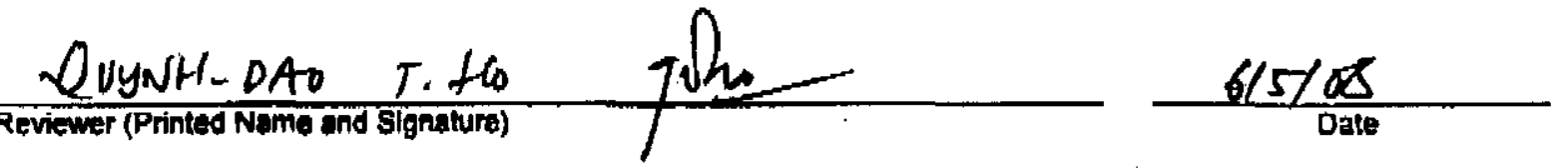

"Any calculations, comments, or notes generated as patt of this reviow should be signed, dated and attached to this checklist. Such material should be ibbeled and recorded in such a manner as to be intelligible to a technically qualified third party. 